\title{
Shorter epilepsy duration is associated with better seizure outcome in temporal lobe epilepsy surgery
}

\section{Curta duração de epilepsia está associada à melhor controle de crises na cirurgia de epilepsia do lobo temporal}

Lucas Crociati Meguins ${ }^{1}$, Rodrigo Antônio Rocha da Cruz Adry , Sebastião Carlos da Silva-Júnior ${ }^{1}$, Gerardo Maria de Araújo Filho², Lúcia Helena Neves Marques ${ }^{3}$

\begin{abstract}
Objective: To investigate the influence of patient's age and seizure onset on surgical outcome of temporal lobe epilepsy (TLE). Method: A retrospective observational investigation performed from a cohort of patients from 2000 to 2012. Results: A total of 229 patients were included. One-hundred and eleven of 179 patients (62\%) were classified as Engel I in the group with < 50 years old, whereas 33 of 50 (66\%) in the group with $\geq 50$ years old group ( $p=0.82$ ). From those Engel I, $88(61 \%)$ reported epilepsy duration inferior to 10 years and $56(39 \%)$ superior to 10 years $(p<0.01)$. From the total of patients not seizure free, $36(42 \%)$ reported epilepsy duration inferior to 10 years and 49 $(58 \%)$ superior to 10 years $(p<0.01)$. Conclusion: Patients with shorter duration of epilepsy before surgery had better postoperative seizure control than patients with longer duration of seizures.
\end{abstract}

Keywords: temporal lobe epilepsy, age at surgery, epilepsy duration, seizure outcome.

RESUMO

Objetivo: Investigar a influência da idade no momento da cirurgia e duração das crises no resultado cirúrgico da epilepsia do lobo temporal (ELT). Método: Estudo observacional retrospectivo de uma coorte de pacientes de 2000 a 2012. Resultados: Um total de 229 pacientes foram incluídos. Cento e onze de 179 pacientes (62\%) foram classificados como Engel I no grupo com < 50 anos de idade, ao passo que 33 de $50(66 \%)$ no grupo com $\geq 50$ anos grupo de idade ( $p=0,82$ ). Daqueles Engel I, 88 (61\%) relataram a duração da epilepsia inferior a 10 anos e 56 (39\%) superiores a 10 anos ( $p<0,01)$. Do total de pacientes não sem crises, $36(42 \%)$ relataram a duração da epilepsia inferior a 10 anos e $49(58 \%)$ superior a 10 anos $(p<0,01)$. Conclusão: Pacientes com menor duração da epilepsia antes da cirurgia tem melhor controle das crises pós-operatório.

Palavras-chave: epilepsia do lobo temporal, idade no momento da cirurgia, duração da epilepsia, controle das crises.

Epilepsy is the most common chronic neurological disease, affecting $0.4 \%$ to $1 \%$ of the general population. The cumulative incidence of seizure is thought to be approximately $10 \%$ to age 74 years, and the lifetime likelihood of receiving a diagnosis of epilepsy is almost $3 \%^{1}$. Temporal lobe epilepsy (TLE) is the most common epilepsy syndrome and affects almost $40 \%$ of epilepsy patients. Several risk factors are associated with epilepsy, such as prolonged childhood febrile seizure, status epilepticus, central nervous system (CNS) infections, head trauma, neoplasm, perinatal/vascular insults, mesial temporal lobe sclerosis (MTS), and a family history of epilepsy ${ }^{2,3,4}$. These risk factors are thought to cause brain injury at a molecular level, leading to either biologic or morphologic changes over years, ultimately leading to the development of refractory epilepsy ${ }^{5}$. Epilepsy surgery has been shown to be an effective treatment, especially for patients with refractory TLE associated with MTS (TLE-MTS), and $60 \%$ to $70 \%$ experience seizure remission ${ }^{6,78,9}$. Therefore, determining presurgical prognostic factors for TLE-MTS is important for identifying ideal candidates and predicting

${ }^{1}$ Faculdade de Medicina de São José do Rio Preto, Hospital Base, Departamento de Ciências Neurológicas, Divisão de Neurocirurgia, Sao José do Rio Preto SP, Brazil;

${ }^{2}$ Faculdade de Medicina de São José do Rio Preto, Departamento de Psiquiatria e Psicologia Médica, Sao José do Rio Preto SP, Brazil;

${ }^{3}$ Faculdade de Medicina de São José do Rio Preto, Hospital Base, Departamento de Ciências Neurológicas, Divisão de Neurologia, Sao José do Rio Preto SP, Brazil.

Correspondence: Lucas Crociati Meguins; Rua Pedro Palotta, 101/31B - Jardim Maracanã; 15092-205 São Paulo SP, Brasil; E-mail: lucascrociati@hotmail.com Conflict of interest: There is no conflict of interest to declare.

Received 14 September 2014; Received in final form 04 November 2014; Accepted 24 November 2014 
the prognosis of individual patients. The aim of the present study was to investigate the influence of age at surgery and seizure onset on the surgical outcome of TLE-MTS patients treated at a Brazilian tertiary center.

\section{METHOD}

\section{Study delineation}

A retrospective observational study was conducted using data collected from consecutive patients with TLE-MTS treated in the Epilepsy service of Faculdade de Medicina de São José do Rio Preto (FAMERP), a Brazilian tertiary referral center, between January 2000 and March 2012. Patients with neuroradiologic evidence and neuropathological confirmation of diseases other than MTS, as well as additional potential epileptogenic lesions on magnetic resonance imaging (MRI), were excluded from the study. Clinical data were retrospectively obtained from the patient records and files. For all patients with a diagnosis of MTS based on MRI, the following data were collected: sex, age at surgery, handedness, type and number of antiepileptic drugs (AEDs) used, and formal neuropsychological evaluation results. Noninvasive video-electroencephalography (EEG) data and surgery side were also registered.

\section{Presurgical evaluation}

All patients underwent noninvasive video-EEG monitoring using the Stella system, Neuro Workbench software, and Nihon Kohden hardware to record epileptic events for later analysis. Every patient was analyzed by an experienced epileptologist as an integral part of inpatient assessment. Patients also completed pre- and postoperative (12 month) neuropsychological assessments. Verbal memory was assessed by a list of learning design, and figural memory by a design learning test using independent items. Memory deficits were defined as performance one standard deviation (SD) below the normal performance of age-matched controls.

Brain MRI was performed with a specific epilepsy protocol using a 1.5-Tesla Philips Scanner. Displaying the sagittal 3D T1-weighted gradient-echo sequences, the next sequences were an axial and coronal fluid-attenuated inversion recovery (FLAIR) fast spin-echo (section thickness, $3 \mathrm{~mm}$ ), axial and coronal T2-weighted fast spin-echo (section thickness, $2 \mathrm{~mm}$ ), and T1-weighted inversion recovery sequences (section thickness, $5 \mathrm{~mm}$ ). All MRIs were analyzed by an experienced neuroradiologist who visually confirmed the radiological diagnosis of MTS, which was determined to be present if atrophy, an increased T2-weighted signal, decreased T1-weighted signal, and disrupted internal structure of the hippocampus were present and accompanied by atrophy of the amygdala and/or temporal pole signal alteration.
Biopsy specimens were obtained from all patients who underwent surgical treatment, and standardized neuropathological analyses were performed. Surgical specimens were microscopically analyzed using hematoxylin-eosin staining. MTS was diagnosed via pathological findings: cell loss in the cornu ammonis CA3 and CA1 pyramidal cells and dentate hilar neurons with relative sparing of the dentate granular cells and CA2 pyramidal cells. The pathologist reported their findings independently of clinical or imaging data. Patients with dual pathology (MTS plus another epileptogenic lesion) were excluded.

\section{Surgical technique}

The surgical approach was similar for all patients, and only one neurosurgeon experienced in surgery for epilepsy (SCS Jr.) performed the surgeries. Patient positioning includes placing a shoulder roll to elevate the trunk and then turning the head 15-20 degrees from the midline so that the operative side is up. The head is slightly extended to bring the sylvian fissure to a perpendicular plane to the operating approach. Finally, dropping the vertex down toward the floor improves surgeon access to mesial structures and allows less retraction on the temporal lobe. A reverse question mark incision was made from just above the zygoma extending back into the temporal region. An anterior temporal craniotomy was performed with respect to the anatomical landmarks of the temporal lobe from the root of the zygoma to the anatomic keyhole. The anterior and lateral remaining bone was removed by drilling down to the limits of the medial fossa floor. At the end of the craniotomy, all bone edges were waxed as necessary, any exposed air cells were sealed, and take-up sutures were performed before opening the dura mater to prevent epidural bleeding. A maximum of 4.0 to $5.0 \mathrm{~cm}$ of the anterior lateral temporal lobe was resected. The mesial resection included amygdala removal and the anterior 2.0 to $3.0 \mathrm{~cm}$ of the hippocampus.

\section{Postsurgical follow-up}

Follow-up investigations were carried out in operated MTS patients 6, 12, and 24 months after surgery. At the 12-month follow-up, all patients completed a neurological examination including observation of behavior disorders, exploration of seizure outcome, and brain MRI in a 1.5-Tesla scanner. Seizure outcome was classified as completely seizure-free since surgery (including auras, i.e. Engel Ia), or not seizure-free (Engel Ib-IV) ${ }^{7}$. Operative mortality was defined as death within 30 days of surgery.

\section{Ethical statement}

The Ethical Committee of our institution analyzed the project and approved our investigation. The study complies with the Declaration of Helsinki. Informed consent was obtained from all patients and/or their legal guardians. 


\section{Statistical analysis}

Statistical analyses were performed with SPSS software (IBM, Chicago, IL, USA). Data collected from all patients were organized in tables and figures. Averages are expressed as means \pm SD for parametric data and median values for nonparametric data. We divided patients into age groups and used the $R^{2}$ coefficient for study its correlation with postoperative outcome of patients. Next, we considered the patients age at surgery as a categorical variable $(<$ or $\geq 50$ years), and Pearson Chi-square coefficients were calculated. For statistical analysis, we performed Chi-square tests to compare epilepsy durations. A p-value $<0.05$ was considered statistically significant for all analyses.

\section{RESULTS}

\section{Presurgical demographic and clinical characteristics}

At the time of the study, 533 patients underwent multidisciplinary epilepsy investigation at our center, and 229 (43\%) fulfilled the inclusion criteria. Most patients excluded from the study did not reach a minimum follow-up of 6 months. In Table 1, the descriptive data analysis is presented as a contingency table with $95 \%$ confidence intervals (CIs) and hypothesis tests.

\section{Seizure control and follow-up}

Figures 1 and 2 and Tables 2 and 3 present seizure-outcome data according to a descriptive analysis of Engel classification

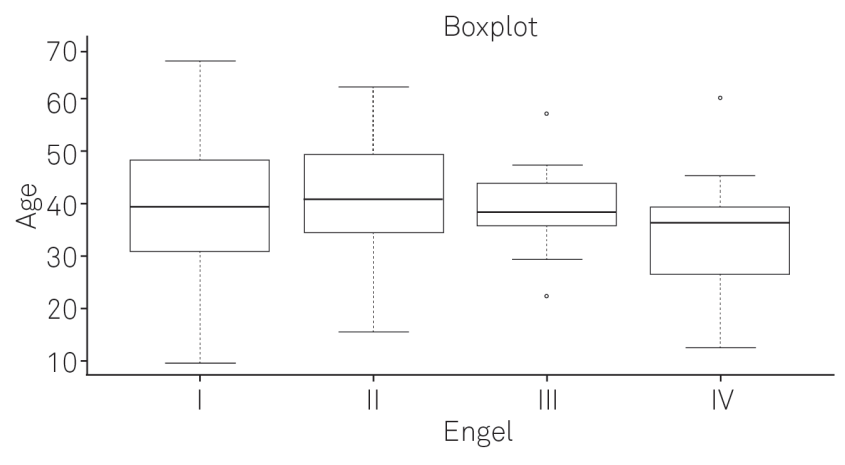

Figure 1. Boxplots of patient age and postoperative Engel classification (I-IV).

for patients $<50$ and $\geq 50$ years old following surgery. Analyzing the correlations between variables with Pearson Chi-square tests (significance level $\alpha=0.05$ ), we observed that patients' age at surgery had no influence on postsurgical outcome $(\mathrm{p}$-value $=0.82)$. Table 4 shows the association between postsurgical seizure outcome (Engel classification) and age distribution. Table 5 and Figure 3 show a descriptive analysis of surgical prognosis according to patient age at surgery.

In Table 6 and Figure 4, the postsurgical seizure outcome distribution according to epilepsy duration at surgery is presented. Among patients who were seizure free (Engel I), 88 $(61 \%)$ reported an epilepsy duration $<10$ years at the time of surgery, compared to $56(39 \%) \geq 10$ years ( $p<0.001)$. In addition, among the patients who were not seizure free after surgery (Engel II-IV), 36 (42\%) and 49 (58\%) reported epilepsy duration $<10$ and $\geq 10$ years, respectively $(\mathrm{p}<0.001)$.

Table 1. Preoperative clinical characteristics of patients with MTS according to age.

\begin{tabular}{|c|c|c|c|c|}
\hline Variable & $\begin{array}{l}<50 \text { years old } \\
n=179(78.1 \%)\end{array}$ & $\begin{array}{l}\geq 50 \text { years old } \\
n=50(21.9 \%)\end{array}$ & $95 \% \mathrm{Cl}$ & $p$-value \\
\hline \multicolumn{5}{|l|}{ Gender } \\
\hline Male & $83(46 \%)$ & $22(44 \%)$ & $-0.14,0.18$ & 0.6 \\
\hline Female & $96(54 \%)$ & $28(56 \%)$ & $-0.18,0.14$ & 0.4 \\
\hline \multicolumn{5}{|l|}{ Handedness } \\
\hline Right & $173(97 \%)$ & $48(96 \%)$ & $-0.04,0.07$ & 0.6 \\
\hline Left & $6(3 \%)$ & $2(4 \%)$ & $-0.07,0.04$ & 0.3 \\
\hline \multicolumn{5}{|l|}{ Risk factors } \\
\hline Febrile seizure & $28(16 \%)$ & $2(4 \%)$ & $-0.04,0.2$ & 0.9 \\
\hline Traumatic brain injury & $10(6 \%)$ & $17(34 \%)$ & $-0.1,0.1$ & 0.5 \\
\hline \multicolumn{5}{|l|}{ Pharmacotherapy } \\
\hline Mono & $28(16 \%)$ & $9(18 \%)$ & $-0.14,0.1$ & 0.3 \\
\hline Combined & $151(84 \%)$ & $41(82 \%)$ & $-0.1,0.14$ & 0.6 \\
\hline \multicolumn{5}{|l|}{ Ictal EEG } \\
\hline Unilateral/Normal & $166(93 \%)$ & $45(90 \%)$ & $-0.06,0.12$ & 0.2 \\
\hline Bilateral & $13(7 \%)$ & $5(10 \%)$ & $-0.12,0.06$ & 0.7 \\
\hline \multicolumn{5}{|l|}{ Interictal EEG } \\
\hline Unilateral & $146(82 \%)$ & $36(72 \%)$ & $-0.04,0.24$ & 0.92 \\
\hline Bilateral & $33(18 \%)$ & $14(28 \%)$ & $-0.24,0.04$ & 0.08 \\
\hline \multicolumn{5}{|l|}{ Surgery side } \\
\hline Left & $85(47 \%)$ & $24(48 \%)$ & $-0.17,0.15$ & 0.4 \\
\hline Right & $94(53 \%)$ & $26(52 \%)$ & $-0.15,0.17$ & 0.5 \\
\hline
\end{tabular}

Cl: Confidence interval; EEG: Electroencephalography; MTS: Mesial temporal lobe sclerosis. 
Table 2. Patient age and postoperative outcome (Engel I-IV).

\begin{tabular}{lcccccccc}
\hline & $\mathrm{n}$ & Mean age & Standard deviation & Minimum & $1^{\text {st }}$ Quartile & $2^{\text {nd }}$ Quartile & $3^{\text {rd }}$ Quartile & Maximum \\
\hline I & 144 & 39.7153 & 11.9162 & 10 & 31.75 & 40 & 49 & 68 \\
II & 56 & 42.0714 & 10.69689 & 16 & 35 & 41.5 & 50 \\
III & 11 & 39.9094 & 8.826144 & 23 & 36.5 & 39 & 44.5 \\
IV & 18 & 34.8333 & 10.81793 & 13 & 28.75 & 37 & 39.75 \\
Total & 229 & 39 & 11.55 & 10 & 33 & 40 & 48 & 61 \\
\hline
\end{tabular}

Table 3. Patient age and postoperative outcome (Engel la-d).

\begin{tabular}{lcccccccc}
\hline & $\mathrm{n}$ & Mean age & Standard deviation & Minimum & $1^{\text {st }}$ Quartile & $2^{\text {nd }}$ Quartile & $3^{\text {rd }}$ Quartile & Maximum \\
\hline la & 117 & 39.77777 & 12.5692 & 10 & 31 & 40 & 49 \\
Ib & 14 & 39.7143 & 8.08375 & 27 & 35.25 & 40 & 42 \\
Ic & 10 & 38.6 & 8.743 & 27 & 31.5 & 37 & 48 \\
Id & 3 & 41 & 9.4163 & 32 & 34.5 & 37 & 45.25 \\
Total & 144 & 39.7153 & 11.9162 & 10 & 31.75 & 40 & 45.5 \\
\hline
\end{tabular}

\section{DISCUSSION}

The present study focused on the influence of age at surgery and seizure onset on the surgical outcome of patients with TLE-MTS treated in a Brazilian epilepsy center. MTS is the most common pathologic abnormality in patients with refractory $\mathrm{TLE}^{10,11,12,13}$, affecting $50 \%$ to $70 \%$ of patients ${ }^{14,15}$. Studies have confirmed that MTS is a chronic disease characterized by prominent neuronal loss and fibrillary gliosis at the level of the hippocampal pyramidal cell layer, but the pathophysiologic mechanisms of hippocampal sclerosis are not fully understood $^{16,17}$. Early surgery is usually recommended because refractory epilepsy may lead to cognitive impairment, poor quality of life, psychosocial dysfunction, and increased morbidity and mortality. If refractoriness is detected early in the course of the disease, aggressive drug therapy or early surgery can improve the responsiveness to treatment and minimize such adverse effects ${ }^{7,18}$. However, there is a lack of information regarding factors that predict the clinical outcome of patients who are surgically treated for TLE-MTS.

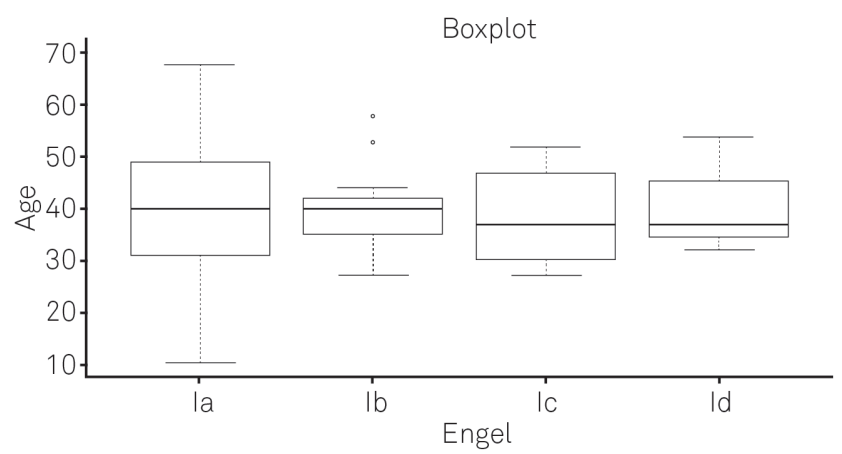

Figure 2. Boxplots of patient age and postoperative Engel classification (la-d).
Jeong et al. ${ }^{19}$ and Junna et al. ${ }^{20}$ observed that a younger age at surgery was predictive of a favorable postsurgical outcome. Additionally, Sirven et al. ${ }^{21}$ studied a large number of patients undergoing temporal lobectomy and observed that patients younger than 50 years had a higher likelihood of seizure freedom compared with those older than 50 years, although the procedure was considered safe and beneficial in both groups. Conversely, a Brazilian investigation reported no statistical difference of age at surgery with regard to postsurgical outcome after temporal lobectomy ${ }^{22}$. We did not observe a statistical difference regarding outcomes between patients younger and older than 50 years at the time of surgery (Table 5); the procedure proved to be safe and beneficial to both groups, which is in accordance with the literature ${ }^{21}$.

Varoglou et al. ${ }^{23}$ recognized early seizure onset as a poor prognostic feature for epilepsy control. Other studies have observed that a longer epilepsy duration before surgical treatment predicted worse seizure outcome ${ }^{19,22}$. However, Baldauf et al. did not reach those conclusions ${ }^{24}$. In the present study, we found that preoperative epilepsy duration $>10$ years was a risk factor for poorer seizure control. In fact, studies have highlighted that longer seizure duration could predispose patients to structural and microbiological changes

Table 4. Postoperative outcome distribution according to age.

\begin{tabular}{lccccc} 
Age & I & II & III & IV & Total \\
\hline $10-19$ & 7 & 3 & 0 & 3 & 13 \\
$20-29$ & 21 & 3 & 1 & 2 & 27 \\
$30-39$ & 39 & 17 & 5 & 8 & 69 \\
$40-49$ & 44 & 18 & 4 & 4 & 70 \\
$50-59$ & 28 & 11 & 1 & 0 & 40 \\
$60-69$ & 5 & 4 & 0 & 1 & 10 \\
Total & 144 & 56 & 11 & 18 & 229 \\
\hline
\end{tabular}


Table 5. Descriptive analysis of surgical outcome according to age at the time of surgery (2-year follow-up).

\begin{tabular}{|c|c|c|c|c|}
\hline \multirow{2}{*}{ Surgical Prognosis } & \multicolumn{2}{|c|}{ Age at Surgery (years) } & \multirow{2}{*}{$95 \% \mathrm{Cl}$} & \multirow{2}{*}{$p$-value } \\
\hline & $<50$ & $\geq 50$ & & \\
\hline la & $89(50 \%)$ & $28(56 \%)$ & $-0.22,0.10$ & 0.23 \\
\hline $\mathrm{Ib}$ & $12(7 \%)$ & $2(4 \%)$ & $-0.04,0.10$ & 0.81 \\
\hline Ic & $8(4 \%)$ & $2(4 \%)$ & $-0.06,0.06$ & 0.5 \\
\hline Id & $3(2 \%)$ & $1(2 \%)$ & $-0.04,0.04$ & 0.5 \\
\hline ॥ & $41(23 \%)$ & $15(30 \%)$ & $-0.21,0.07$ & 0.17 \\
\hline III & $10(5 \%)$ & $1(2 \%)$ & $-0.02,0.08$ & 0.88 \\
\hline IV & $16(9 \%)$ & $1(2 \%)$ & $0.01,0.13$ & 0.99 \\
\hline \multicolumn{5}{|c|}{ Engel la vs. Others (Ib-IV) } \\
\hline Engel la & 89 (49\%) & $28(56 \%)$ & $-0.23,0.09$ & 0.19 \\
\hline Others (Ib-IV) & $90(51 \%)$ & $22(44 \%)$ & $-0.09,0.23$ & 0.81 \\
\hline \multicolumn{5}{|c|}{ Engel I vs. Others (II-IV) } \\
\hline Engel I & $112(63 \%)$ & $33(66 \%)$ & $-0.18,0.12$ & 0.35 \\
\hline Others (II-IV) & $67(37 \%)$ & $17(34 \%)$ & $-0.12,0.18$ & 0.65 \\
\hline
\end{tabular}

Cl: Confidential interval.

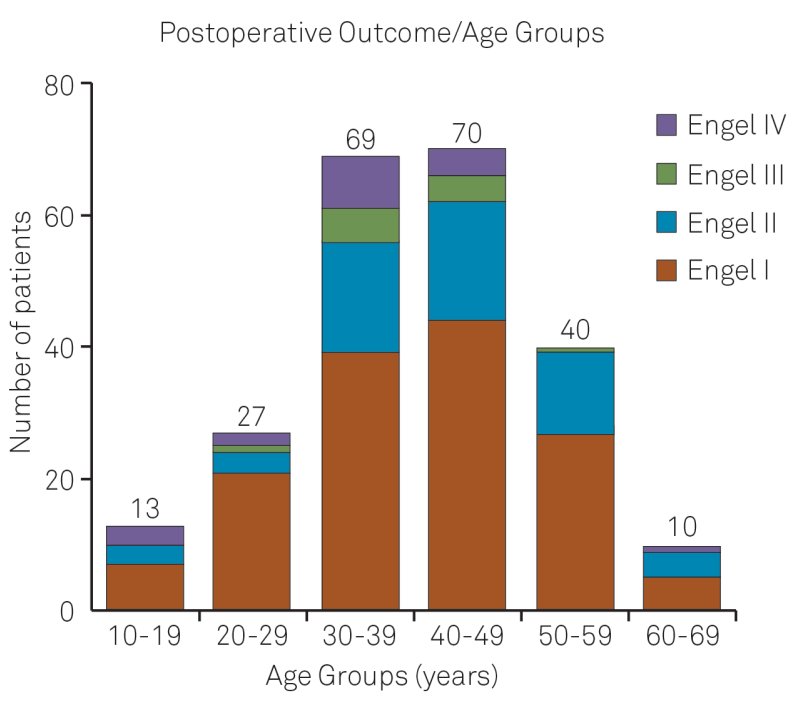

Figure 3. Postoperative outcome distribution according to age (2-year follow-up).

in other brain areas not involved in the primary epileptogenic zone, and this could be associated with the persistence of disabling seizures ${ }^{19,20,21,22,23,24}$. However, further clinical and experimental investigations are necessary to validate this hypothesis.

There are several methodological aspects of the present study that should be considered when interpreting the

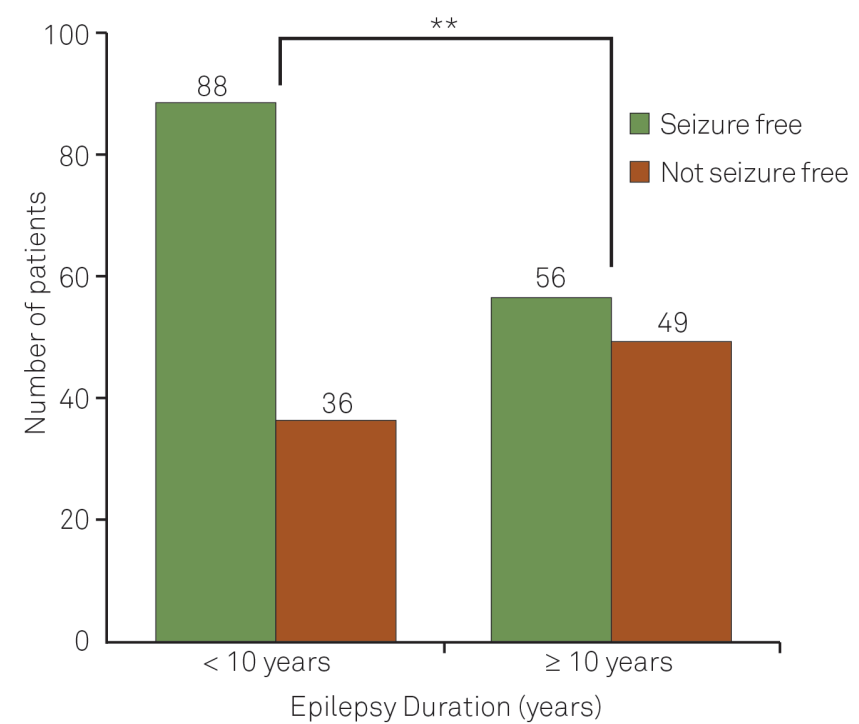

Figure 4. Seizure outcome according to epilepsy duration $(<10$ and $\geq 10$ years). ${ }^{* *}$ p-value: 0.0089. Seizure free: Engel I; Not Seizure free: Engel II-IV; 2-year follow-up.

results. Firstly, although a large number of patients were included, the study population represented less than $50 \%$ of all patients who underwent surgery for TLE-MTS at our institution. Because the epilepsy center receives patients from all regions from Brazil, a large number of patients were lost due to the countries size and associated transportation

Table 6. Seizure outcome according to epilepsy duration ( $<10$ and $\geq 10$ years, 2 -year follow-up).

\begin{tabular}{|c|c|c|c|}
\hline & & & \\
\hline & $<10$ years & $\geq 10$ years & Total \\
\hline Seizure free & $88(61 \%)$ & $56(39 \%)$ & 144 \\
\hline Not seizure free & $36(42 \%)$ & $49(58 \%)$ & 85 \\
\hline
\end{tabular}

Seizure free: Engel I; Not Seizure free: Others (Engel II-IV); ${ }^{\star} p<0.001$; Chi-square test. 
difficulties. Secondly, this study was a retrospective investigation with nonrandomized surgical case series without a control group. Therefore, future prospective and randomized studies with a greater number of patients are necessary to confirm our findings.
In conclusion, our results highlight that prolonged seizure history before surgery is an important negative prognostic factor that must be considered. Early recognition and surgical treatment of patients with refractory TLE-MTS may improve seizure outcome and patient quality of life.

\section{References}

1. Hauser WA, Annegers JF, Rocca WA. Descriptive epidemiology of epilepsy: contributions of population-based studies from Rochester, Minnesota. Mayo Clin Proc. 1996;71(6):576-86. http://dx.doi.org/ 10.4065/71.6.576

2. Fanciulli M, Di Bonaventura C, Egeo G, Fattouch J, Dazzo E, Radovi S et al. Suggestive linkage of familial mesial temporal lobe epilepsy to chromosome 3q26. Epilepsy Res. 2014;108(2):232-40. http://dx.doi. org/10.1016/j.eplepsyres.2013.11.002

3. Tezer FI, Akalan N, Oguz KK, Karabulut E, Dericioglu N, Ciger A et al. Predictive factors for postoperative outcome in temporal lobe epilepsy according to two different classifications. Seizure. 2008;17(6):549-60. http://dx.doi.org/10.1016/j.seizure.2008.02.003

4. Burneo JG, Black L, Martin R, Devinsky O, Pacica S, Faught E et al. Race/ethnicity, sex, and socioeconomic status as predictors of outcome after surgery for temporal lobe epilepsy. Arch Neurol. 2006;63(8):1106-10. http://dx.doi.org/10.1001/archneur.63.8.1106

5. Herman ST. Epilepsy after brain insult: targeting epileptogenesis. Neurology. 2002;59(9 Suppl 5):S21-6.

6. Cohen-Gadol AA, Wilhelmi BG, Collignon F, White JB, Britton JW et al. Long-term outcome of epilepsy surgery among 399 patients with nonlesional seizure foci including mesial temporal lobe sclerosis. J Neurosurg. 2006;104(4):513-24.

7. Engel J Jr, McDermott MP, Wiebe S, Langfitt JT, Stern JM, Dewar S et al. Early surgical therapy for drug-resistant temporal lobe epilepsy: a randomized trial. JAMA. 2012;307(9):922-30. http://dx. doi.org/10.1001/jama.2012.220

8. Fiest KM, Sajobi TT, Wiebe S. Epilepsy surgery and meaningful improvements in quality of life: results from a randomized controlled trial. Epilepsia. 2014;55(6):886-892. http://dx.doi.org/10.1111/epi.12625

9. Wiebe S, Blume WT, Girvin JP, Eliasziw M. A randomized, controlled trial of surgery for temporal-lobe epilepsy. N Engl J Med. 2001;345(5):311-8. http://dx.doi.org/10.1056/NEJM200108023450501

10. Kim WJ, Park SC, Lee SJ, Lee JH, Kim JY, Lee BI et al. The prognosis for control of seizures with medications in patients with MRI evidence for mesial temporal sclerosis. Epilepsia. 1999;40(3):290-3. http://dx.doi.org/10.1111/j.1528-1157.1999.tb00706.x

11. Semah F, Picot MC, Adam C, Broglin D, Arzimanoglou A, Bazin B et al. Is the underlying cause of epilepsy a major prognostic factor for recurrence? Neurology. 1998;51(5):1256-62.

12. Stephen LJ, Kwan P, Brodie MJ. Does the cause of localisationrelated epilepsy influence the response to antiepileptic drug treatment? Epilepsia. 2001;42(3):357-62. http://dx.doi.org/10.1046/ j.1528-1157.2001.29000.x

13. Van Paesschen W, Duncan JS, Stevens JM, Connelly A. Etiology and early prognosis of newly diagnosed partial seizures in adults: a quantitative hippocampal MRI study. Neurology. 1997;49(3):753-7.

14. Lee DH, Gao FQ, Rogers JM, Gulka I, Mackenzie IR, Parrent AG et al. $\mathrm{MR}$ in temporal lobe epilepsy: analysis with pathologic confirmation. AJNR Am J Neuroradiol. 1998;19(1):19-27.

15. Margerison JH, Corsellis JA. Epilepsy and the temporal lobes: a clinical, electroencephalographic and neuropathological study of the brain in epilepsy, with particular reference to the temporal lobes. Brain. 1966;89(3):499-530. http://dx.doi.org/10.1093/brain/89.3.499

16. Bernasconi A. Magnetic resonance imaging in intractable epilepsy: focus on structural image analysis. Adv Neurol. 2006;97:273-8.

17. Cendes F, Caramanos Z, Andermann F, Dubeau F, Arnold DL. Proton magnetic resonance spectroscopic imaging and magnetic resonance imaging volumetry in the lateralization of temporal lobe epilepsy: a series of 100 patients. Ann Neurol. 1997;42(5):737-46. http://dx.doi. org/10.1002/ana.410420510

18. Langfitt JT, Wiebe S. Early surgical treatment for epilepsy. Curr Opin Neurol. 2008;21(2):179-83. http://dx.doi.org/10.1097/WC0.0b013e3282f47931

19. Jeong SW, Lee SK, Hong KS, Kim KK, Chung CK, Kim H. Prognostic factors for the surgery for mesial temporal lobe epilepsy: longitudinal analysis. Epilepsia. 2005;46(8):1273-9. http://dx.doi.org/10.1111/j.15281167.2005.33504.x

20. Junna MR, Buechler R, Cohen-Gadol AA, Mandrekar J, Christianson T, Marsh R et al. Prognostic importance of risk factors for temporal lobe epilepsy in patients undergoing surgical treatment. Mayo Clin Proc. 2013;88(4):332-6. http://dx.doi.org/10.1016/j.mayocp.2013.01.011

21. Sirven JI, Malamut BL, O’Connor MJ, Sperling MR. Temporal lobectomy outcome in older versus younger adults. Neurology. 2000;54(11):2166-70.

22. Prevedello DM, Sandmann MC, Ebner A. Prognostic factors in mesial temporal lobe epilepsy surgery. Arq Neuropsiquiatr. 2000;58(2A):207-13. http://dx.doi.org/10.1590/S0004-282X2000000200001

23. Varoglu AO, Saygi S, Acemoglu H, Ciger A. Prognosis of patients with mesial temporal lobe epilepsy due to hippocampal sclerosis. Epilepsy Res. 2009;85(2-3):206-11. http://dx.doi.org/10.1016/j.eplepsyres.2009.03.001

24. Baldauf CM, Cukiert A, Argentoni M, Baize-Zung C, Forster CR, Mello VA et al. Surgical outcome in patients with refractory epilepsy associated to MRI-defined unilateral mesial temporal sclerosis. Arq Neuropsiquiatr. 2006;64(2B):363-8. http://dx.doi.org/10.1590/S0004-282X2006000300003 